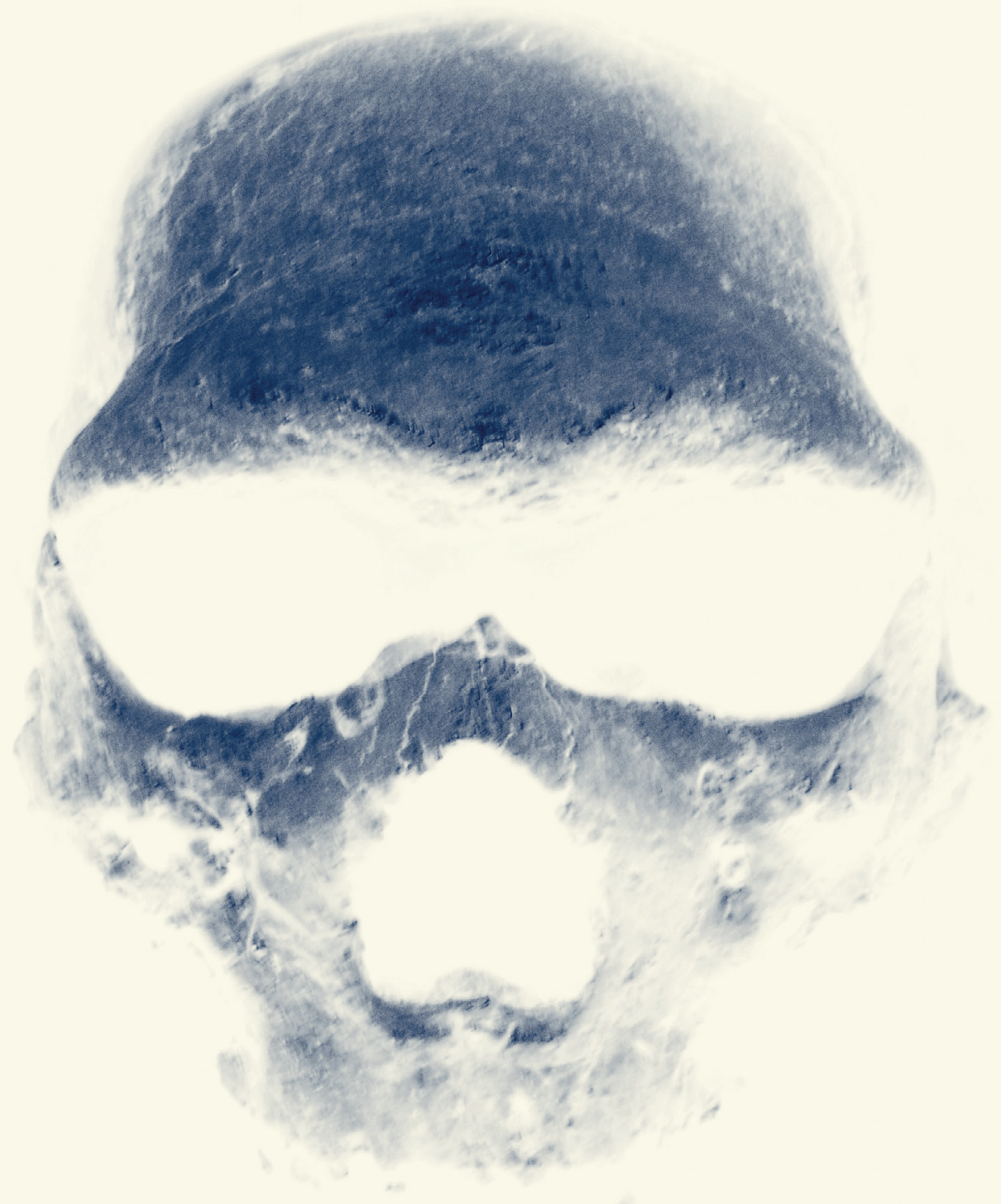

\title{
Ghosts in the cave
}

A mysterious group of ancient humans known as Denisovans is helping to rewrite our understanding of human evolution. Who were they?

BY EWEN CALLAWAY 
$\mathbf{S}$ amantha Brown didn't have high hopes when she opened the ziplock bag containing some 700 shards of bone. It would be a lot of work to analyse them and none was likely to be human, she had been warned.

The fossils were from Denisova Cave - an archaeological site in southern Siberia where, in 2010, scientists had discovered a previously unknown group of ancient humans ${ }^{1}$. Researchers had identified them, whom they named Denisovans, on the basis of DNA preserved in a finger bone, and that finding had made the remote shelter one of the most important archaeological sites in the world.

Brown went through her bag of bones, testing each for proteins that are distinctly hominin. She found bears, bison, hyenas and even mammoths and rhinoceroses, but no trace of any hominins. So she flew to Siberia to collect more bone samples that had been excavated from Denisova Cave, knowing that her chances of success were slim.

Her luck turned in June 2015, when a 2-centimetre sliver of long bone tested positive for hominin collagen. "It was such an insane moment to find out that one of them was a hominin," she says. Yet nothing would prepare her for a subsequent discovery by colleagues in Germany, who had sequenced the complete genome of DNA in the bone. Last year, a team that included Brown reported that the bone belonged to a woman who had lived around 100,000 years ago, and whose mother was a Neanderthal and father a Denisovan ${ }^{2}$. They gave the remarkable young woman a name: Denny.

"It was such a one-in-a-million find in the first place - and then for it to be a first-generation offspring. It's magic, it's amazing," Brown says. "It's a real testament to what we can still find."

Brown and her colleagues have since discovered other hominin bone fragments in Denisova Cave, and the team is embarking on a project to analyse tens of thousands of bone shards from the cave and further sites in Asia. The effort is one of several that are extending the search for Denisovans across the continent, where traces of their DNA are found in many modern human populations. Researchers hope to determine the range of this enigmatic group - which might have stretched from Siberia to Oceania - and to chart its encounters with other hominins, including Homo sapiens and Neanderthals. Many scientists dream of finding more complete Denisovan remains and artefacts, so that they can work out what Denisovans looked like and begin to understand how they might have behaved.

Almost one decade after their discovery, Denisovans are finally coming into focus. Scientists are gaining confidence that they will soon uncover more remains of this ancient population from sites other than Denisova cave - if they haven't already. Researchers have raised the possibility that some unusual fossils in China might be Denisovan.

"It's really a hunt to find Denisovans," says Andrey Krivoshapkin, an archaeologist at the Institute of Archeology and Ethnography of the Siberian Branch of the Russian Academy of Sciences in Novosibirsk, who is excavating caves near Denisova and sites in central Asia for clues.

\section{A HERMIT'S CAVE}

Denisova Cave lies at the foot of the Altai Mountains, near Russia’s borders with Mongolia, China and Kazakhstan. Located in a verdant river valley that reminds some visitors of Switzerland, the site gets its name, according to legends, from a local herder or an eighteenth-century hermit who found seclusion in its high-ceilinged chambers. The cave remains remote, even for the researchers who flock there during the six-month excavation season that spans the spring and summer. "You are completely cut off from the world," says Katerina Douka, an archaeological scientist and Brown's supervisor at the Max Planck Institute for the Science of Human History in Jena, Germany, who first visited the cave in 2013. "It was a paradise," she says.

Soviet archaeologists began to excavate the cave in the 1970s and early 1980s, discovering tens of thousands of stone tools and fragments of animal bone, many gnawed and digested by hyenas or other carnivores that had lived in the cave. In 2009, Svante Pääbo, a geneticist at the Max
Planck Institute for Evolutionary Anthropology in Leipzig, Germany, received a bone from the finger of a hominin, small and broken in half, that Russian archaeologists had pulled from the cave the previous year. He wondered whether it belonged to a Neanderthal, because his team had found the group's DNA in fragmentary remains from a cave nearby. But Pääbo's expectations were low because the bone was so small and therefore unlikely to contain much DNA. "It was actually lying around for half a year," he says, before his team analysed it.

Denisova 3, as the bone is now known, raised questions that scientists are still grappling with. As well as revealing the existence of the mysterious new hominins ${ }^{1}$, the DNA found in it suggested that Denisovans and Neanderthals are both descended from an ancestral population that, further research has shown, diverged from that of modern humans in the past 800,000 years, and probably lived throughout $\mathrm{Asia}^{3}$. Humans across the continent still carry Denisovan ancestry in varying proportions.

Denisova Cave is still the only place where Denisovans have been found, and discoveries such as Denny suggest that the site was once a nexus for various groups of human. When it comes to understanding such interactions, Pääbo adds: "It's one of the most - if not the most - important sites in the world."

In the years that followed the discovery of Denisovans, scientists used DNA sequencing to attribute a few molar teeth from the cave to the same group ${ }^{4}$. They have also found other remains that harboured Neanderthal DNA. The analysis of Denny fills in some important details about the two groups. "We knew that Denisovans and Neanderthals had been there. We just didn't think they interacted this intimately," says Pääbo. "It was so amazing to find direct proof - to find these people in the act, almost, of mixing."

Denny's discovery has also convinced Pääbo and other scientists that the remains of similar individuals, with recent ancestry from two groups of hominin, will be found - perhaps also in Denisova Cave. Researchers who analysed Denny's genome found signs that the chromosome set that was contributed by her father, although clearly Denisovan, harboured some Neanderthal ancestry, which hints at earlier encounters between the groups ${ }^{2}$. "We should be able to pick up these individuals," says Douka.

"It's still a head scratcher," adds Tom Higham, an archaeological scientist at the University of Oxford, UK, who works with Douka and Brown. "It's either an incredible piece of luck, or interbreeding happens so frequently that we might expect to find these types of occurrence in the archaeological record."

\section{BUSY CROSSROADS}

Although some researchers hope to stumble on another Denny, others are trying to identify periods when different groups of hominin overlapped - and perhaps interbred - in the cave. Geochronologists Zenobia Jacobs and Richard Roberts at the University of Wollongong, Australia, led a team that dated sediment from Denisova Cave by analysing hundreds of thousands of grains of quartz and feldspar.

Judging by the oldest stone tools found there, the cave's first residents moved in around 300,000 years ago and were, presumably, Denisovans or Neanderthals. Denisovans occupied the cave from at least 200,000 years ago to about 55,000 years ago - when the sediments in which Denisova 3 was found were laid down, Jacobs and Roberts reported in January ${ }^{5}$. The team also dated Neanderthal remains and sediment to between about 100,000 and 190,000 years ago.

This could imply that the two groups overlapped for long stretches, but Jacobs cautions that the team cannot yet pinpoint such periods, in part, because of the scarcity of hominin remains. Pääbo's team is scouring the hundreds of sediment samples from Jacobs and Roberts' study for hominin DNA, which could help to nail down when Denisovans and Neanderthals occupied the cave and whether they overlapped.

There are also clues that modern humans inhabited the cave and perhaps encountered these other groups. In the cave's younger deposits, archaeologists have uncovered tools and jewellery sculpted from 
the bones and teeth of deer and other animals that resemble artefacts associated with the first $H$. sapiens to reach Europe, during a period known as the Initial Upper Palaeolithic, which began roughly 50,000 years ago. In another paper published in January ${ }^{6}$, a team led by Douka and Higham calculated that these artefacts were 43,000-49,000 years old. However, a hominin bone fragment that was $46,000-50,000$ years old lacked the DNA needed to pin it to a specific group.

The Russian archaeologists who led the cave's excavation have proposed that the tools and jewellery were made by Denisovans and suggest that the group had the capacity for symbolic thinking. But archaeologists in the West tend to favour the idea that the artefacts were made by early modern humans, whose remains have been found at another Siberian site, Ust'-Ishim ${ }^{7}$, and date to the Initial Upper Palaeolithic.

Researchers are now searching the younger sediments of Denisova Cave for more hominin remains and DNA that could help to uncover who made the artefacts. Similar work at other archaeological sites in Siberia, including several in the vicinity of Denisova Cave, could also yield answers, says Higham. "There's a lot of really exciting stuff happening. Things are moving quite fast."

\section{SEARCH FOR BONES}

Researchers have been held back by a lack of fossil evidence of Denisovans. Bence Viola has studied the lot, including Denisova 3 - which was ground up for DNA analysis - and several unusually large molars that do not resemble those of Neanderthals or modern humans ${ }^{8}$. "All the Denisovan material fits in a very, very small box," says Viola, a palaeoanthropologist at the University of Toronto, Canada. "I've spent a lot of time staring at these very small fragments and teeth. I am probably the only one who's seen it all."

But more material is emerging slowly. Archaeologists excavating Denisova Cave in 2016 discovered a freshly broken chunk of parietal bone - part of the skull - that contains mitochondrial DNA from a Denisovan. The bone is shaped a bit like that of Homo erectus, a species of hominin that most researchers consider to be a close ancestor of humans, Neanderthals and, presumably, Denisovans (see 'Tangled tree'). "Sadly, it's not very informative. I expected more of it," says Viola, who will describe his analysis in March at the annual meeting of the American Association of Physical Anthropologists. He hopes that the other pieces of the parietal bone, or even a complete skull, might soon be found. "It would be nice to have somewhat more," he adds.

There seems to be no shortage of fragmentary remains. Earlier this month, Higham tweeted a picture of a long-bone fragment in a small plastic bag. "Good luck little Denisovan bone," he wrote, although he doesn't yet know to which hominin group it belongs. It was the fifth bone from the cave, including Denny's remains, to be identified as hominin by the team. The researcher used a method called zooarchaeology by mass spectrometry (ZooMS), which was developed to quickly identify the animal bones that often litter archaeological sites. ZooMS breaks collagen, the most abundant protein in bone, into smaller peptides, and then uses a mass spectrometer to identify differences between animal species. Hominins have identical collagen peptide sequences, so DNA is needed to pin remains to specific groups.

On the back of early successes, Douka and her colleagues won $€ 2$ million (US\$2.3 million) in European Research Council funding in 2017 to expand the search for Denisovans to some 20 sites across Europe and Asia by sifting through another 30,000-40,000 bones. "There are days I'm very hopeful, and there are days where you go through a thousand bones and find a thousand hyenas," says Douka. "I have a feeling China is the place to look."

Other scientists share Douka's hunch, largely owing to the distribution of Denisovan DNA in modern humans - it is common in many Chinese populations. Some scientists wonder whether there might even be a Denisovan skeleton already knocking around a museum collection in China. In 2017, for instance, palaeoanthropologists described the unusually large skulls of hominins that lived 105,000-125,000 years ago, excavated from a site near the city of Xuchang in central China ${ }^{9}$. On the basis of their age, location and distinct anatomy, the remains have got
TANGLED TREE

Denisova Cave in Siberia was home to Neanderthals, modern humans and a group of ancient hominins known as Denisovans. Evidence suggests that the groups interbred at points in the past, some in the vicinity of the cave.

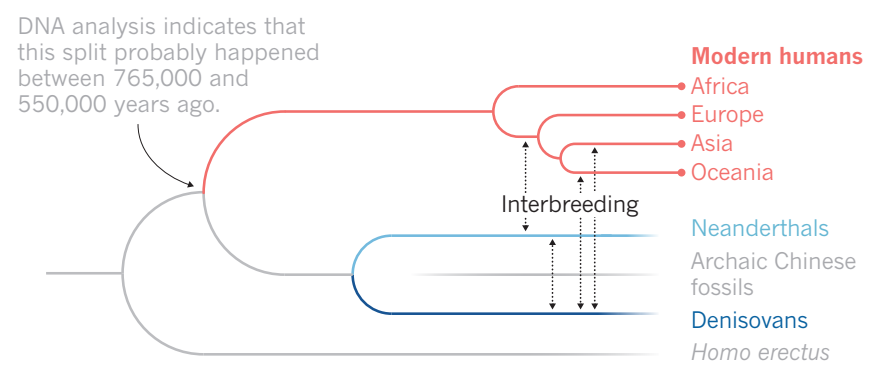

some researchers, including Chris Stringer, a palaeoanthropologist at the Natural History Museum in London, wondering whether they might belong to Denisovans. "Who are the Denisovans outside of Denisova Cave?" Stringer says. "They've got to be there in China."

Viola says that the Xuchang skulls don't resemble his parietal bone fragment. He's more interested in the roughly 300,000-year-old remains from a site in northern China called Xujiayao, which contain molars that look similar to those from Denisova Cave. "I would be very surprised if it turns out that some of the material from China, especially Xujiayao, is not Denisovan," says Viola.

A team led by geneticist Qiaomei Fu, who has established an ancientDNA lab at the Chinese Academy of Sciences' Institute of Vertebrate Paleontology and Paleoanthropology in Beijing, has analysed the Xuchang skulls and those from other potential Denisovans, but says that none of the remains, so far, has contained any hominin DNA.

Proteins might offer researchers a better shot at finding a Denisovan in China or elsewhere in Asia, because they tend to persist longer than DNA. Douka has just recruited a PhD student in China to comb through samples there, and she also hopes to analyse remains from southeast Asia and Papua New Guinea.

Because the form of collagen that ZooMS looks at does not differ between Denisovans and other hominins, researchers will need to sequence bone proteins that show more variation to find a Denisovan. Frido Welker, a molecular anthropologist at the Natural History Museum of Denmark in Copenhagen, has just begun a project to see whether hominin remains, including those of potential Denisovans, from the early and middle Pleistocene epoch - a period that spanned 2.6 million to 126,000 years ago — harbour proteins that indicate evolutionary relationships. "That's a time period when ancient DNA does not survive necessarily, but where proteins do," says Welker.

Many scientists now presume that Denisova Cave was a northern outpost that Denisovans and other hominins called home when the climate allowed. Yet even long after those ancient populations disappeared from the site, it remains a magnet for disparate groups. In July 2018, anthropologists, archaeologists and geneticists who have become obsessed with the cave gathered there to share their latest finds. The conference was called 'The Origins of the Upper Palaeolithic in Eurasia and the evolution of the genus Homo' but it might as well have been dubbed Denisovastock.

It was Brown's first visit, and she knew that she would be wowed by the cave that has yielded so many discoveries. She says that the surrounding landscape, lush and green, gave her a glimpse at what drew in Denny and her relatives. "You can just imagine people wanting to be there." -

\section{Ewen Callaway writes for Nature from London.}

1. Krause, J. et al. Nature 464, 894-897 (2010).

2. Slon, V. et al. Nature 561, 113-116 (2018)

3. Meyer, M. et al. Nature 531, 504-507 (2016).

4. Slon, V. et al. Sci. Adv. 3, e1700186 (2017).

5. Jacobs, Z. et al. Nature 565, 594-599 (2019).

6. Douka, K. et al. Nature 565, 640-644 (2019).

7. Fu, Q. et al. Nature 514, 445-449 (2014).

8. Sawyer, S. et al. Proc. Natl Acad. Sci. USA 112, 15696-15700 (2015).

9. Li, Z. Y. et al. Science 355, 969-972 (2017). 